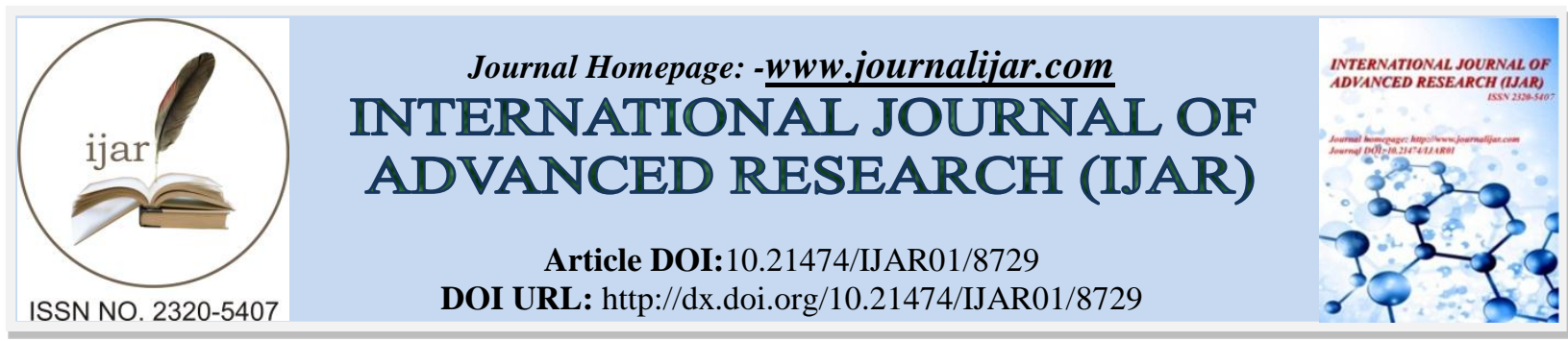

SHORT COMMUNICATION

\title{
TUMOR SIZE OF BREAST CANCER AMONG ATTENDEES TO EARLY DETECTION CLINIC IN IRAQ.
}

Hiba D. Al-Ameri ${ }^{1}$, Hayder K. Hanash Al-Jaberi ${ }^{2}$, Mohammed Al-Hilli ${ }^{3}$ and Jawad K. Al-Diwan ${ }^{4}$.

1. MB ChB, FABHS(CM), Al-Imamein al Kadhimaein Medical City, Early Detection Clinic of Breast Cancer.

2. MB ChB, FIBMS(RAD), Al-Imamain al Kadhimaein Medical City, Head of Radiology Department.

3. MB ChB, DMRD, FICMS(RAD), Medical City Complex-Baghdad, Chairman of Scientific Council of Radiodiagnosis and Medical Imaging.

4. MB ChB, MSc, DCN, FIBMS, FFPH, Dept. of Family and Community Medicine, College of Medicine, Baghdad University.

\section{Manuscript Info}

\section{Manuscript History}

Received: 18 January 2019

Final Accepted: 20 February 2019

Published: March 2019

Copy Right, IJAR, 2019,. All rights reserved.

In Iraq, the age adjusted rate of breast cancer is 31.5 per $100000^{1}$. It was reported that patients with breast cancer usually presented in late stage because low index of suspicion and lack of population-based breast cancer screening program. ${ }^{2}$ Only a national program for early detection of breast cancer was established in $2000 .^{3}$ This study was carried out to report on size of breast tumor at early detection clinic in west northern Baghdad.

A review of 506 case files of women with breast cancer in early detection clinic in Al-Kadhimia Teaching Hospital (west northern Baghdad) was done. They were selected randomly for the period 2009 to 2018. Required information was age and primary estimation of tumor size by ultrasound.

The size of tumor was $25.1 \pm 12.9 \mathrm{~mm}$. Fig. 1 shows the age distribution of breast ca. It was revealed that 291 $(57.5 \%)$ of tumor sized $>20 \mathrm{~mm}$. The age of women with breast ca was $51.2 \pm 11.7$ year. The age of those with sized $>20 \mathrm{~mm}$ was $50.4 \pm 11.8$ year and those with breast ca sized $\leq 20 \mathrm{~mm}$ was $52.2 \pm 11.4$ year. No significant difference in age between different tumor size $(\mathrm{t}=1.6$, d.f. $=504, \mathrm{p}=0.09)$ and no significant difference in tumor size from 2009 to $2018\left(\chi^{2}=12.2\right.$, d.f $=9$, $\left.\mathrm{p}=0.2\right)$.

In the line of that reported in $\mathrm{Iraq}^{3}$, the age at diagnosis of breast ca was $51.2 \pm 11.7$ year.

The observed large tumor size $(25.1 \pm 12.9 \mathrm{~mm})$ might be attributed to lack of adequate health care infrastructure i.e. no population-based breast ca screening program in Iraq, and only early detection clinics were established in tertiary hospitals. ${ }^{3}$

The study showed that $57.5 \%$ of tumor size was $>20 \mathrm{~mm}$. It is like that reported in Iran. The observed finding is lower than that reported in Sudan (33 mm), Tunisia $(51 \mathrm{~mm})$ ), Oman (46 mm), and Egypt (32 mm), Kenya (68 mm), and Tanzania $(71 \mathrm{~mm}){ }^{4}$ Although it seems difference in tumor size, however, all the figures refer to large size of tumor. It was reported that breast ca in Eastern Europe, Middle East, Mexico, the Caribbean and South America present at earlier age, with large aggressive tumors. 
It is in contrast with report from United States showing an increase by $15 \%$ in the rate of tumor $<20 \mathrm{~mm}$ in the period 1990 to $1998 .^{5}$ Survival of patients with breast was direct function of tumor size. ${ }^{6}$

Iraq is in urgent need for population based screening program in primary health care center to ensure accessibility of services.

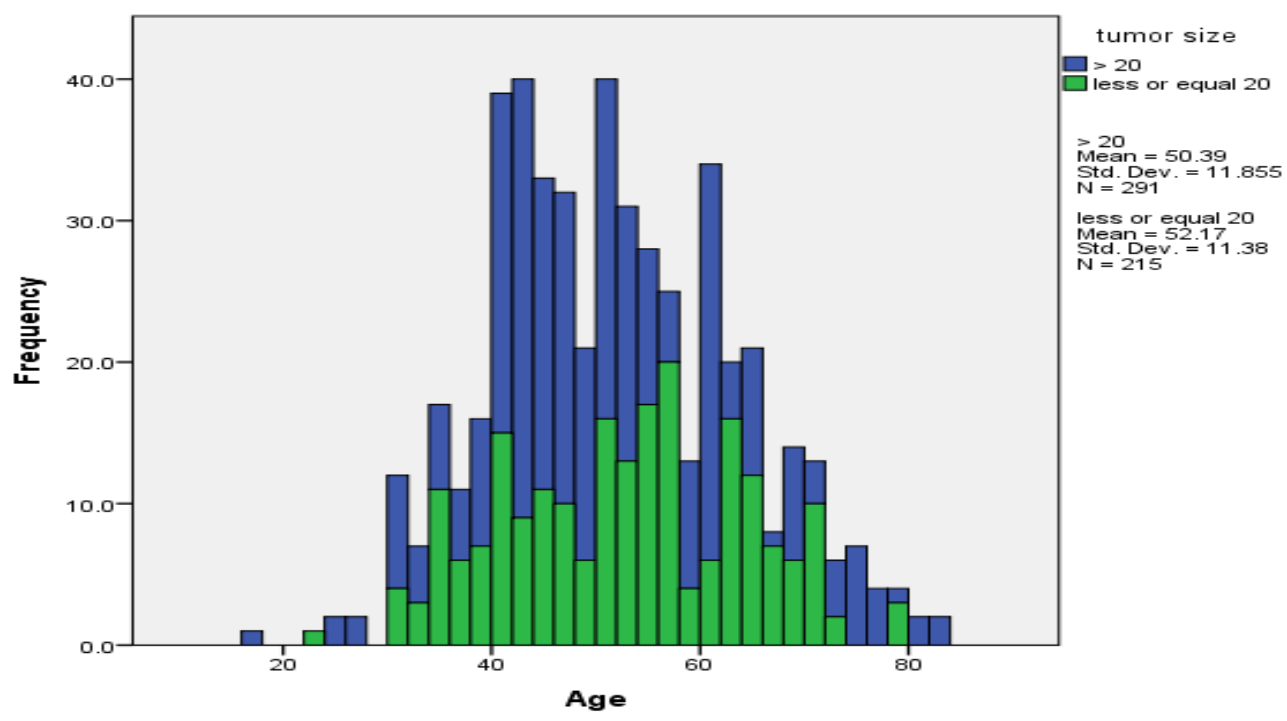

Figure 1:-Age distribution of breast cancer

\section{References:-}

1. Al-Hashmi YM, Wang XJ. Breast cancer in Iraq, incidence trend from 2000 - 2009. Asian Pac J Cancer Prev 2014; 15: 281-286.

2. Alwan NAS. Breast cancer among Iraqi women: preliminary findings from regional comparative breast cancer research project. J Glob Oncol 2016; 2: 1-4.

3. Abedalrahman SK, Al-Khalidy NA, Al-Hashimi AS, Al-Diwan JK. Accuracy of FNAB in diagnosis of breast lump. IJPHRD 2019; 10:

4. Bhikoo R, Srinivasa S, Yu TC, Moss D, Hill AG. Systematic review of breast cancer biology in developing countries (part 1): Africa, the middle East, eastern Europe, Mexico, the Caribbean and South America. Cancers. $2011 ; 3: 2358-81$.

5. Vas-Luis I, Huges ME, Brustein HJ, Weeks JC, Winer EP, Lin NU et al. Outcomes and treatment pattern tumor subtypes and treatment pattern in women with small, node negative breast cancer: multi-institutional study. J Clin Oncology 2014; 20: 2142-2150.

6. Michaelin JS, Sliverstein M, Waytt J, Weber G, Moore R, Halperch E et al. Predicting of survival of patients with breast cancer using tumor size. Cancer 2002; 95: 713-723. 